\title{
Ground water level and moisture regime monitoring of land use types in the Szigetköz
}

\author{
Kálmán RAJKAI ${ }^{1}$ - Gábor KOLTAI ${ }^{2}-$ Zsolt GICZI $^{2}$
}

1: Institute for Soil Science and Agricultural Chemistry Centre for Agricultural Research; 1022 Budapest, Herman O. u. 15. E-mail: rajkai.kalman@agrar.mta.hu

2: Agricultural and Food Sciences Faculty of Széchenyi István University, 9200 Mosonmagyaróvár, Vár tér 2. E-mail: koltai.gabor@sze.hu; giczi.zsolt@sze.hu

Keywords: soil moisture measurement, water table depth, environmental and land use factors, soil moisture storage

\section{Introduction}

In the flood protected areas of the Szigetköz, which are affected by the Danube, mainly grassland and arable crops are being cultivated. In the Dunaremete-Lipót region there is a typical meadow lawn In 1995, the soil moisture monitoring program was started with two weekly, or monthly measurements within the growing season, in order to follow the soil moisture dynamics due to change of the ground water table level. Indeed, the groundwater level is sensitive to the diversion of the Danube into the new riverbed and to the lower water flow into the old Danube riverbed. Besides following the ground water table level the soil moisture content profiles were collected and evaluated in selected agricultural areas of the Szigetköz (Koltai et al., 2008; Koltai et al, 2010).

\section{Materials and methods}

Soil moisture content $(\theta \%)$ we collected with a BR-150 probe (Andrén et al., 1992) in $10 \mathrm{~cm}$ soil layer resolution. For detecting effects of the Danube diversion to the new riverbed, we evaluated the T-03 (Dunakiliti), the T-09 arable lands (Kisbodak), and the T-04 grassland (Dunaremete) of the monitoring program in the Szigetköz. For comparing different crop yields their relative values are used. The extent to which the crop yields of the arable crops and the mowing meadow depend on the variation to rainfall, groundwater table depth and soil moisture storage we analyze statistically.

\section{Results and discussion}

Crop yields of the monitored arable fields are determined mostly by the soil water storage of the extended rooting zone $(0-150 \mathrm{~cm})$, the ground water table depth, and the

Table 1: Crop yields, soil water storage and ground water table depth of arable fields in Dunakiliti (T-03) and Kisbodak (T-09)

\begin{tabular}{|c|c|c|c|c|c|c|c|c|}
\hline \multirow{2}{*}{ Year } & \multirow{2}{*}{ Crop } & \multicolumn{2}{|c|}{$\begin{array}{c}\text { Yield } \\
\mathrm{t} / \mathrm{ha}\end{array}$} & \multicolumn{2}{c|}{$\begin{array}{c}\text { Water storage } \\
0-150 \mathrm{~cm} \\
\mathrm{~mm}\end{array}$} & \multicolumn{2}{c|}{$\begin{array}{c}\text { Water table } \\
\text { depth } \\
\mathrm{m}\end{array}$} & $\begin{array}{c}\text { Precipitation } \\
\text { Apr.-Aug. } \\
\mathrm{mm}\end{array}$ \\
\cline { 3 - 8 } & & $\mathrm{T}-03$ & $\mathrm{~T}-09$ & $\mathrm{~T}-03$ & $\mathrm{~T}-09$ & $\mathrm{~T}-03$ & $\mathrm{~T}-09$ & \\
\hline 1998 & Corn & 9.6 & 10.0 & 283 & 391 & -343 & -266 & 356 \\
\hline 2000 & Wheat & 5.3 & 6.0 & 281 & 351 & -349 & -262 & 165 \\
\hline 2003 & Wheat & 3.6 & 5.3 & 289 & 395 & -367 & -293 & 244 \\
\hline
\end{tabular}




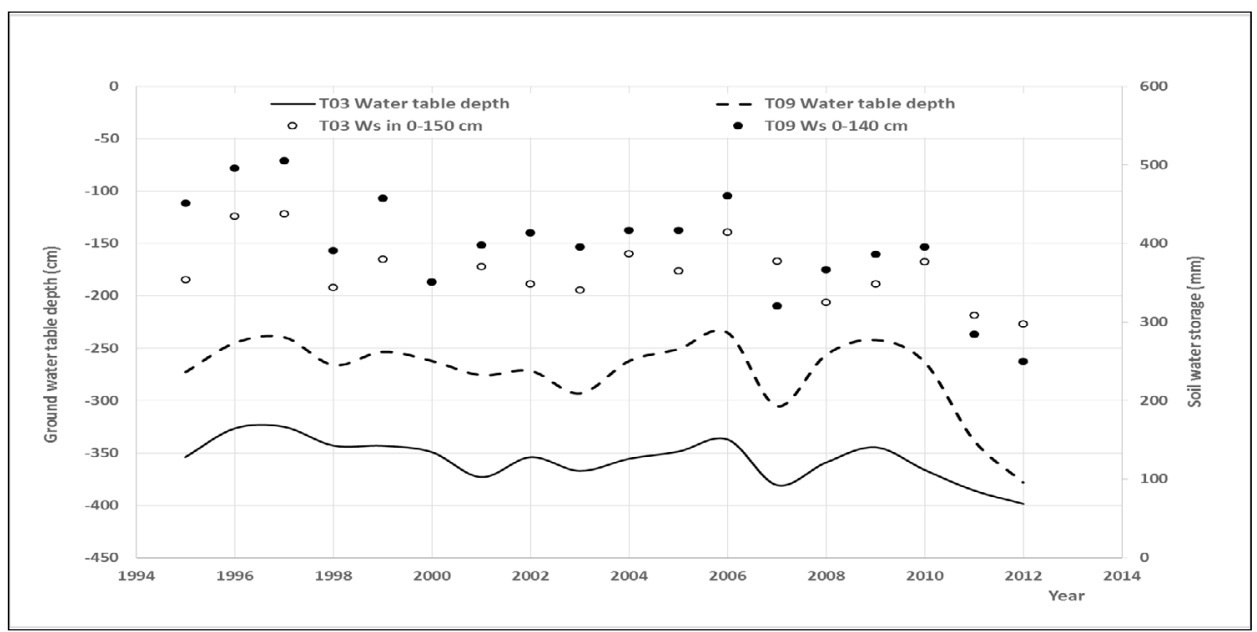

Figure 1: Ground water table depth and water storage of the 0-150 cm soil depth as annual averages between 1995 and 2012.

\section{Conclusions}

Rather qualitative conclusions can be drawn only from the monthly resolution soil moisture content data collection started in 1995. For improving the resolution of data collections, daily soil moisture data collection was started in four sites in 2018.

\section{Acknowledgement}

Authors thanks for the Government Resolution 2030/1995 (II.8) on environmental monitoring, and the KmF-118/2018. Groundwater data were provided by the NorthTransdanubian Water Directorate, and weather data by the Mosonmagyaróvár station.

\section{References}

Andrén O., Rajkai K., Katterer T. (1991): A non-destructive technique for studies of root distribution in relation to soil moisture. Ecosystem and Environment. 34. 269-278. DOI: https://doi.org/10.1016/01678809(91)90114-D

Koltai, G., Milics G., Neményi M., Nagy V., Rajkai K. (2008): Plant water supply of layered alluvial soils under different weather conditions: Proceedings of the VII. Alps-Adria Scientific Workshop, Szlovákia, Stara Lesna, 2008. April 28 - May 2. Cereal Research Communication. 36. 5: 167-170.

DOI:https://doi.org/10.1556/CRC.36.2008.Suppl.1

Koltai G, Hegedűs M.F., Végh R.K., Tomáš O., Rajkai K. (2010): Soil moisture monitoring as resilience indicator on the Danube lowlands. Növénytermelés. 59: Suppl. 291-294. DOI:10.1556/Novterm.59.2010.Suppl.3 